\title{
PENINGKATAN KONSEP DIRI TERHADAP PRESTASI BELAJAR SISWA (STUDI KASUS DI SMK WALISONGO JAKARTA)
}

\author{
Hendro Prasetyono \\ Universitas Indraprasta PGRI, Indonesia \\ hendro_prasetyono@unindra.ac.id
}

\begin{abstract}
Received: 29 Agustus 2020 Konsep diri merupakan salah satu bagian dari kepribadian individu yang
Revised: 10 September 2020 diduga memiliki dampak terhadap prestasi belajar peserta didik di SMK

Accepted: 15 September 2020 Walisongo Jakarta. Pendekatan penelitian adalah kuantitatif dengan metode survei. Populasi penelitian merupakan siswa siswi kelas XI Jurusan Akuntansi 1 dan Akuntansi 2 di Sekolah Menengah Kejuruan Walisongo Jakarta Selatan sejumlah 76 siswa. Jumlah sampel yang dihitung dengan Rumus Slovin didapatkan hasil sebesar 43 responden dan teknik pengambilan sampel adalah simple random sampling. Pengambilan data menggunakan kuesioner dengan teknik analisis data menggunakan analisis korelasi, koefisien korelasi, regresi linear dan uji t. Hasil penelitian koefisien korelasi diperoleh $r_{\mathrm{xy}}=0,765$ artinya terdapat pengaruh yang kuat atau tinggi antara pengaruh konsep diri peserta didik terhadap belajar akuntansi dengan analisis koefisien determinasi diperoleh sebesar $58,225 \%$. Persamaan regresi $\mathrm{Y}=17,91+0,805 \mathrm{X}$. Pengujian hipotesis menunjukkan $t_{\text {hitung }}>\mathrm{t}_{\text {tabel }}(7,605>2,021)$ artinya Ho ditolak dan Ha diterima maka dapat disimpulkan bahwa peningkatan konsep diri siswa berpengaruh terhadap prestasi belajar peserta didik pada mata pelajaran akuntansi.
\end{abstract}

Keywords: Konsep Diri; Prestasi Belajar; Siswa SMK

(*) Corresponding Author: $\quad$ Prasetyono, hendro_prasetyono@unindra.ac.id, 08568537188

How to Cite: Prasetyono, H. (2020). Peningkatan Konsep Diri Terhadap Prestasi Belajar Siswa (Studi Kasus Di SMK Walisongo Jakarta). Research and Development Journal of Education, 1(1), 49-59.

\section{INTRODUCTION}

Sekolah Menengah Kejuruan (SMK) merupakan lembaga pendidikan formal di Indonesia yang berfungsi menghasilkan lulusan yang siap kerja sedang mendapatkan perhatian penuh dari pemerintah. Hal tersebut dibuktikan dengan keluarnya Instruksi Presiden (InPres) No 9 tahun 2016 tentang Revitalisasi Sekolah Menengah Kejuruan diharapkan dapat supplemen peningkatan kualitas SMK. SMK dalam sistem pendidikan nasional Indonesia bertujuan untuk meningkatkan generasi penerus bangsa yang memiliki kecerdasan, pengetahuan, kepribadian, akhlak mulia, serta keterampilan untuk hidup mandiri dan mengikuti pendidikan lebih lanjut sesuai dengan kejuruannya (Putro \& Triyono, 2016). Sehingga Pendidikan vokasi dapat dikatakan sebagai salah satu institusi utama dalam mencetak generasi bangsa yang berkualitas.

Walaupun pemerintah saat ini telah serius dalam meningkatkan kualitas SMK kenyataanya belum sesuai dengan apa yang diharapkan. Kondisi tersebut terlihat dari ketidakpuasan pihak terkait, khususnya masyarakat dunia industri terhadap peserta didik lulusan SMK (Indriaturrahmi \& Sudiyatno, 2016). Fakta konsep link and match masih memiliki permasalahan seperti kekurangan guru berkualitas, sulit memenuhi biaya operasional sekolah yang tinggi, sarana dan prasarana untuk praktek yang masih kurang, 
kurikulum yang silih berganti, dan masalah pemeliharaan serta perbaikan sarana dan prasarana sekolah (Sutrisno \& Siswanto, 2016). Oleh karena itu perlu dikaji secara empiris penyebab utama terjadi gap antara kualitas lulusan dengan kebutuhan dunia industri.

Prestasi belajar siswa merupakan salah satu indicator dalam kemajuan kualitas Pendidikan (Gerritsen-van Leeuwenkamp, Joosten-ten Brinke, \& Kester, 2019). Prestasi belajar secara umum dapat diukur dan diketahui secara kuantitatif melalui ujian, tes atau ulangan harian.Pengukuran belajar siswa dapat dilakukan secara berkala atau secara periodik sesuai dengan ketentuan atau kalender akademik yang dilakukan mandiri oleh sekolah (Iim Inayah \& Khoiri, 2013).

Tinggi rendahnya prestasi belajar siswa yang menunujukkan tingkat keberhasilan belajarnya, dapat dipengaruhi beberapa faktor, baik dari dalam (internal) maupun dari luar diri (eksternal) siswa (Setiawati, 2015). Faktor internal terdiri atas faktor fisiologis (kesehatan jasmani dan rohani), dan faktor psikologis (intelegensi, konsep diri, perhatian, minat, bakat, motif, kematangan, kesiapan). Faktor eksternal yaitu faktor di luar siswa antara lain : lingkungan belajar baik di seolah, keluarga maupun masyarakat, guru dan cara mengajarnya, dan alat yang digunakan dalam belajar (Andinny, 2015; Wiyani, 2013).

Diantara beragam faKtor yang mempengaruhi prestasi belajar siswa, penulis tertarik untuk melihat aspek konsep diri karena masih terdapat beberapa hasil penelitian membuktikan konsep diri mempengaruhi prestasi belajar siswa dan memiliki kontribusi di atas 30\% setelah dihitung koefisien determinasinya (Alamsyah, 2016; Andinny, 2015; Fortunately, Asmendri, \& M. Haviz, 2019; Hartuti, 2015; Magfirah, Rahman, \& Sulasteri, 2015). Hasil ini sangatlah besar jika dibandingkan dengan beragam variable lain yang berkontribusi terhadap prestasi belajar.

Konsep diri didefinisikan sebagai keyakinan, pandangan dan penilaian individu terhadap dirinya sendiri (Alamsyah, 2016). Jika dikaitkan dengan prestasi belajar perlu dibangun konsep diri yang bersifat positif agar terbentuk kepercayaan diri siswa. Peserta didik dalam menilai dirinya terkadang menimbulkan penilaian positif dan ada yang menilai negatif.

Hasil grandtour yang dilakukan oleh penulis dengan cara observasi partisipan dan wawancara tidak terstruktur kepada beberapa peserta didik di SMK Walisongo Jakarta mayoritas memiliki konsep diri yang positif. Hal ini terlihat dari perasaan optimisme, kepercayaan diri yang tinggi, berprasangka positif terhadap segala sesuatu yang terjadi pada dirinya dan juga terhadap kemalangan atau kegagalan yang dialaminya. Kegagalan bukan merupakan tanda berakhirnya kehidupan, akan tetapi dijadikan sebagai batu loncatan untuk meraih kesuksesan dimasa mendatang.

Konsep diri positif seperti ini sangat diperlukan khususnya oleh peserta didik SMK karena salah satu tujuan Pendidikan vokasi adalah menciptakan wirausaha yang trampil dan tangguh (Darmastuti \& Karwanto, 2014). Konsep diri yang positif ini didapatkan oleh peserta didik karena guru-guru SMK Walisongo dalam mengajar menyisipkan nilainilai Islam khususnya para sahabat nabi. Oleh karena itu penulis tertarik untuk melakukan kajian empiris pengaruh konsep diri terhadap prestasi belajar siswa di SMK Walisongo Jakarta Selatan.

\section{Prestasi Belajar}

Menurut Tu'u (2004:47) prestasi belajar berarti penguasaan pengetahuan atau keterampilan tertentu yang dikembangkan dari suatu mata pelajaran yang umumnya ditunjukkan dengan nilai tes atau angka yang telah diberikan oleh guru. Prestasi merupakan hasil yang dicapai seseorang ketika mengerjakan tugas atau kegiatan tertentu. Menurut Purwodarminta (2005:56) "prestasi belajar adalah sesuatu yang dicapai." 
Prestasi belajar ini dapat diketahui dari evaluasi tes yang di dalamnya mengukur tentang kecakapan dan kemampuan seseorang ataupun pengetahuannya dalam belajar (Tamrin, PH, \& Soenarto, 2018). Prestasi ini mengacu terhadap sesuatu yang telah dicapai seseorang yang dapat diketahui dengan evaluasi dalam bentuk tes namun tes standar mempunyai beberapa kelemahan karena hanya mengukur kemampuan seseorang terhadap pengetahuannya dalam belajar (Warren \& Hale, 2016).

Hasil prestasi belajar peserta didik mayoritas dipengaruhi oleh berbagai faktor yang berasal dari dalam dirinya maupun dari luar dirinya (Thomas, 2013). Prestasi belajar yang dicapai peserta didik sejatinya merupakan hasil interaksi factor dari dalam diri sisiwa dan luar siswa tersebut. Oleh karena itu, guru harus dapat mengenali faktor-faktor yang dapat meningkatkan atau menurunkan prestasi belajar siswa dalam rangka membantu siswa mencapai prestasi yang seoptimal mungkin dengan kemampuan masing-masing (Setiawati, 2015).

Menurut Slameto (2003:54), ada beberapa faktor-faktor yang memengaruhi belajar dapat dikategorikan menjadi 2 faktor yaitu : (1) Faktor intern adalah faktor yang berasal dari dalam diri individu peserta didik, terdiri dari tiga faktor yaitu: faktor jasmaniah dan faktor psikologis; (2) Faktor ekstern adalah faktor yang berasal dari luar individu peserta didik. Faktor ekstern dapat dikategorikan menjadi tiga faktor yaitu : keluarga, sekolah dan masyarakat.

\section{LITERATURE REVIEW}

\section{Konsep Diri}

Menurut Ghufron dan Rini (2010:13) konsep diri didefinisikan sebagai deskripsi individu terhadap diri sendiri yang merupakan kesatuan dari kondisi fisik, psikologi, sosial, emosional aspiratif dan prestasi yang telah dicapai. Berpijak pada prinsip Gestalt dalam Surna dan Panderiot (2014:140) yaitu tanggapan dan pemahaman seseorang tergantung pada medan pengamatan dan pengalaman yang utuh dan didasarkan pada persepsi yang disadari dan nilai-nilai diri. Konsep diri adalah bagian sadar dari ruang fenomenal yang disadari dan disimboliskan yaitu diri sebagai pusat referensi dari setiap pengalaman (Surjanti, Soejoto, \& Nugroho, 2020). Seseorang yang memiliki pengalaman hidup mendalam dapat turut meningkatkan kemampuan seseorang dalam memahami dirinya (Guay, et all, 2019).

Menurut Myers dalam Sobur (2013:507) bahwa citra diri dan penghargaan diri adalah suatu perasaan yang didapatkan pada saat tindakan sesuai dengan kesan pribadi dan pada saat kesan khusus memprediksi suatu versi yang diidealkan mengenai bagaimana kita mengungkapkan diri kita sendiri. Individu yang menilai dirinya sendiri dengan orang lain ada yang menilai positif dan ada yang menilai negatif. Hal ini berarti setiap individu ada yang memiliki konsep diri positif dan diri negatif sesuai dengan persepsinya masing-masing.

Menurut Brook dan Emeret dalam Rakhmat (2007:105) ada lima tanda orang berkonsep diri positif, yaitu yakin akan kemampuan diri sendiri dalam mengatasi masalah, merasa sama strata sosialnya dengan orang lain, menerima dengan ikhlas pujian tanpa rasa malu dan tidak menghilangkan rasa rendah hati. Sehingga individu yang memiliki konsep diri yang tinggi akan menerima pujian dan tidak membanggakan dirinya apalagi meremehkan orang lain. Tanda berikutnya adalah menyadari bahwa setiap orang memiliki berbagai perasaan dan keinginan. Individu akan peka terhadap perasaan orang lain sehingga akan menghargai perasaan orang lain. Selanjutnya, individu tersebut akan mampu memperbaiki karena individu tersebut sanggup mengungkapkan aspek-aspek 
kepribadian tidak disenangi orang lain dan berusaha mengubahnya. Mampu untuk mengintrospeksi dirinya sendiri sebelum mengintrospeksi orang lain dan mampu mengubahnya menjadi lebih baik lagi agar diterima di lingkungannya.

Sobur (2013: 517) mengatakan bahwa faktor orang lain dan kelompok rujukan sebagai faktor-faktor yang memengaruhi konsep diri". Seseorang mengenal diri sendiri dengan mengenal orang lain terlebih dahulu. Bagaimana orang lain menilai diri kita, maka hal itu akan membentuk konsep diri kita. Tidak semua orang mempunyai pengaruh yang sama terhadap diri kita. Ada memang yang paling berpengaruh, yaitu orang-orang yang paling dekat dengan diri kita. Jika seseorang diterima oleh orang lain, dihormati dan disenangi karena keberadaan individu tersebut, maka individu tersebut akan cenderung bersikap menghormati dan menerima. Sebaliknya, bila orang lain selalu meremehkan, menyalahkan dan menolak kita, kita akan cenderung tidak akan menyenangi diri kita. Pendapat lain menyatakan 4 faktor mempengaruhi konsep diri, yakni (1) self appraisal, (2) reaction and responses of others, dan (3) roles you play. (4) reference group (Mynott, 2018).

\section{METHODS}

Penelitian ini menggunakan pendekatan kuantitatif dengan metode survey karena penelitian ini berusaha mengetahui pengaruh variable bebas terhadap variable terikat (Hendro Prasetyono, Abdillah, \& Fitria, 2018). Populasi penelitian ini adalah peserta didik kelas XI Jurusan Akuntasi SMK Walisongo Jakarta Selatan yang berjumlah 76 orang siswa. Jumlah sampel dihitung menggunakan rumus Slovin dengan toleransi $10 \%$ didapatkan hasil 43 responden. Teknik pengambilan sampel menggunakan simple random sampling karena tidak ada pertimbangan khusus dalam pemilihan sampel dan jumlah siswa dianggap homogen sehingga diambil secara acak (Nurfarhana, Abdillah, \& Prasetyono, 2017).

Instrument variable konsep diri pengambilan data menggunakan kuesioner dengan kisi-kisi yang dikembangkan dari indicator variable yang tersaji pada table berikut:

Tabel 1.

Kisi-kisi Instrumen Variabel Konsep Diri

\begin{tabular}{|c|c|c|c|c|c|}
\hline No. & $\begin{array}{c}\text { Indikator } \\
\text { konsep diri }\end{array}$ & & Sub Indikator & $\begin{array}{c}\text { No Butir } \\
\text { Soal } \\
\end{array}$ & Jumlah \\
\hline \multirow{8}{*}{1.} & \multirow{6}{*}{ Positif } & 1) & Mengatasi masalah yang & 1,2 & \multirow{6}{*}{10} \\
\hline & & & dihadapi & 3,4 , & \\
\hline & & 2) & Setara dengan orang lain & 5,6 & \\
\hline & & 3) & Rendah hati & 7,8 & \\
\hline & & 4) & Menghargai perasaan orang lain & 9,10 & \\
\hline & & 5) & Mampu menginstropeksi diri & & \\
\hline & & 1) & Peka Kritik, mudah marah & 11,12 & \\
\hline & & 2) & Rsponsive terhadap pujian & 13,14 & \\
\hline \multirow[t]{4}{*}{2.} & Negatif & 3) & Bersikap hiperkritis & 15,16 & 10 \\
\hline & & 4) & Merasa rendah diri & 17,18 & \\
\hline & & 5) & Pesimis terhadap kompetisi & 19,20 & \\
\hline & \multicolumn{3}{|r|}{ Jumlah soal } & & 20 \\
\hline
\end{tabular}

Sumber : Peneliti 
Berdasarkan kisi-kisi instrument tersebut disusun 20 butir pernyataan dalam bentuk kuesioner. 20 pernyataan tersebut diuji valiliditasnya kepada 20 responden dan terdapat 3 butir item yang tidak valid karena nilai $r_{\text {hitung }}$ dibawah 0,44 . Sehingga 17 butir item yang valid diuji reliabilitas dan didapatkan koefisien $r_{11}$ sebesar 0,876 yang berarti sangat reliabel.

Variabel prestasi belajar datanya diambil dari nilai tes yang diberikan oleh peneliti yang telah diuji validitas, reliabilitas, daya pembeda, tingkat kesukaran (Saputra \& Prasetyono, 2020). Butir tes disusun menyesuaikan materi yang tengah dipelajari saat itu, yaitu materi Sistem Ekonomi sejumlah 30 butir soal. Setelah diuji ternyata hanya 20 butir tes yang valid, reliabel, daya pembeda baik dan tingkat kesukaran yang normal. Teknik analisis data dengan pendekatan kuantitatif diawali analisis korelasi, regresi linear sederhana dan uji hipotesis (H. Prasetyono, Abdillah, Widiarto, \& Sriyono, 2018).

\section{RESULTS \& DISCUSSION}

\section{Result}

1. Analisis Koefisien Korelasi

Analisis korelasi sederhana digunakan untuk mengetahui seberapa besar pengaruh konsep diri siswa terhadap prestasi belajar ekonomi akuntansi kelas XI Akuntansi 1 dan 2 di SMK Walisongo Jakarta. Maka teknik analisis data yang digunakan dalam penelitian ini mengunakan uji koefisien korelasi (product momen). Adapun untuk mengetahui besarnya koefisien korelasi, maka dilakukan langkah perhitungan sebagai berikut:

$$
\begin{array}{llll}
\Sigma \mathrm{X} & =3513 & \Sigma \mathrm{Y}^{2} & =304642 \\
\Sigma \mathrm{Y} & =3598 & \Sigma \mathrm{XY} & =296552 \\
\Sigma \mathrm{X} 2 & =290237 & \mathrm{n} & =43
\end{array}
$$

Selanjutnya dihitung menggunakan perhitungan korelasi product moment sebagai berikut :

$$
\begin{aligned}
r_{\mathrm{xy}} & =\frac{\left(n \cdot \sum X Y\right)-\left(\sum X\right)\left(\sum Y\right)}{\sqrt{\left.\left\{n \cdot \sum X^{2}-\left(\sum X\right)^{2}\right\} n \cdot \sum Y^{2}-\left(\sum Y\right)^{2}\right)}} \\
& =\frac{43 \cdot(296552)-(3513) \cdot(3598)}{\sqrt{43.290237-(12341169) \cdot(43.304642-(12945604)}} \\
& =\frac{111962}{\sqrt{21409666044}} \\
& =0,765
\end{aligned}
$$

Dari hasil perhitungan korelasi diatas dapat disimpulkan bahwa koefisien korelasi $r_{\mathrm{xy}}=0,765$ artinya terdapat hubungan yang kuat antara konsep diri siswa terhadap prestasi belajar ekonomi akuntansi (Sugiyono, 2010:250).

2. Analisis Koefisien Determinasi

Metode ini digunakan untuk mengetahui seberapa besar kontribusi konsep diri tehadap prestasi belajar ekonomi akuntansi dengan menggunakan rumus (Sekaran, 2003) :

$$
\mathrm{KD} \quad \begin{aligned}
& =r^{2} \times 100 \% \\
& =0,765^{2} \times 100 \%
\end{aligned}
$$




$$
\begin{aligned}
& =0.585225 \times 100 \% \\
& =58,225 \%
\end{aligned}
$$

Dari perhitungan diatas didapatkan Koefisien Determinasi (KD) sebesar 0.585225 atau 58,225\%. Hal ini berarti bahwa konsep diri memberikan kontribusi terhadap prestasi belajar ekonomi akuntansi sebesar 58,225\% sedangkan sisanya sebesar $41,775 \%$ dipengaruhi oleh faktor-faktor lain, yang tidak diikutsertakan dalam penelitian ini.

3. Analisis Regresi Linear Sederhana

Regresi linear sederhana adalah regresi didasarkan pada hubungan fungsional ataupun kausal satu variabel independen dengan satu variabel dependen (Gorard, 2004). Adapun rumus regresi linear sederhana : $\mathbf{Y}=\mathbf{a}+\mathbf{b X}$

Adapun hasil persamaan regresi diketahui nilai :

$$
\begin{array}{rlrl}
\Sigma \mathrm{X} & =3513 \quad \sum \mathrm{Y}=3598 & \sum \mathrm{X}^{2}=290237 \\
\Sigma \mathrm{Y}^{2} & =304642 \quad \sum \mathrm{XY}=296552 & \mathrm{n} & =43 \\
\mathrm{~b} & =\frac{n \cdot \sum X Y-\sum X \sum Y}{n \cdot \sum X^{2}-\left(\sum X\right)^{2}} \\
& =\frac{43(296552)-(3513)(3598)}{43(290237)-(3513)^{2}} \\
& =\frac{12751736-12639774}{12480191} \\
\mathrm{~b} & =\frac{111962}{139002} \\
\mathrm{~b} & =0,805 \\
\bar{X} & =\frac{\sum X}{n}=\frac{3513}{43}=81,69 \\
\bar{Y} & =\frac{\sum Y}{n}=\frac{3598}{43}=83,67 \\
\mathrm{a} \quad & =\bar{Y}-\mathrm{b} \bar{X} \\
& =83,67-(0,805) .(81,69) \\
& =83,67-65,76 \\
& =17,91
\end{array}
$$

Setelah diketahui analisis menunjukkan bahwa besarnya nilai $\mathrm{a}=17,91$ dengan koefisien $b=0,805$ sehingga ditemukan persamaan regresinya adalah sebagai berikut : $\mathrm{Y}=17,91+0,805 \mathrm{X}$. Nilai konstanta sebesar 17,91 yang berarti jika koefisien konsep diri nilainya adalah 0 , maka nilai prestasi belajar adalah 17,91. Koefisien regresi variable konsep diri sebesar 0,805 yang berarti jika terjadi kenaikan konsep diri sebesar 1 poin maka akan terjadi peningkatan prestasi belajar sebesar 0,805 poin.

4. Pengujian Hipotesis

Pengujian hipotesis dilakukan untuk membuktikan Hipotesis (Ho) atau hipotesis alternatif yang diterima, maka langkah selanjutnya adalah membandingkan $t_{\text {hitung }}$ dengan $t_{\text {tabel }}$. Untuk mengetahui keberartian korelasi konsep 
diri siswa terhadap prestasi belajar ekonomi akuntansi. Oleh karena itu dilakukan uji t dengan langkah-langkah sebagai berikut :

a. Formulasi Hipotesis

Ho : $p=0$, artinya tidak ada pengaruh antara konsep diri siswa terhadap prestasi belajar ekonomi akuntansi.

Ho : $p \neq 0$, artinya ada pengaruh antara konsep diri siswa terhadap prestasi belajar ekonomi akuntansi.

b. Menentukan $t_{\text {hitung }}$

$$
\begin{aligned}
t & =\frac{r \sqrt{n-2}}{\sqrt{1-r^{2}}} \\
& =\frac{0,765 \sqrt{43-2}}{\sqrt{1-(0,765)^{2}}} \\
& =\frac{0,765 \sqrt{41}}{\sqrt{1-0,585225}} \\
& =\frac{0,765 \cdot 6,403}{\sqrt{0,414775}} \\
& =\frac{4,898}{0,644} \\
& =7,605
\end{aligned}
$$

Maka diperoleh $t_{\text {hitung }}$ adalah 7,605

c. Nilai a dan $t_{\text {tabel }}$

Setelah diketahui nilai thitung maka $t_{\text {hitung }}$ dibandingkan dengan nilai $\mathrm{t}_{\text {tabel. }}$ Taraf signifikasi kesalahan yang digunakan $(\mathrm{a})=5 \%$ uji dua fihak dan derajat kebebasan $(\mathrm{dk})=\mathrm{n}-2$

Dimana nilai kritis pengujian dapat diperoleh dari tabel distribusi $\mathrm{t}$ dengan rumus sebagai berikut :

$$
\begin{aligned}
& \mathrm{a}=5 \% \\
& \mathrm{Dk}=\mathrm{n}-2=43-2=41 \\
& \text { Untuk } \mathrm{t}-\mathrm{a}(\mathrm{dk}=\mathrm{n}-2)
\end{aligned}
$$

maka diperoleh tabel $=2,021$

d. Kriteria Pengujian

Kriteria pengujian dalam penelitian ini adalah:

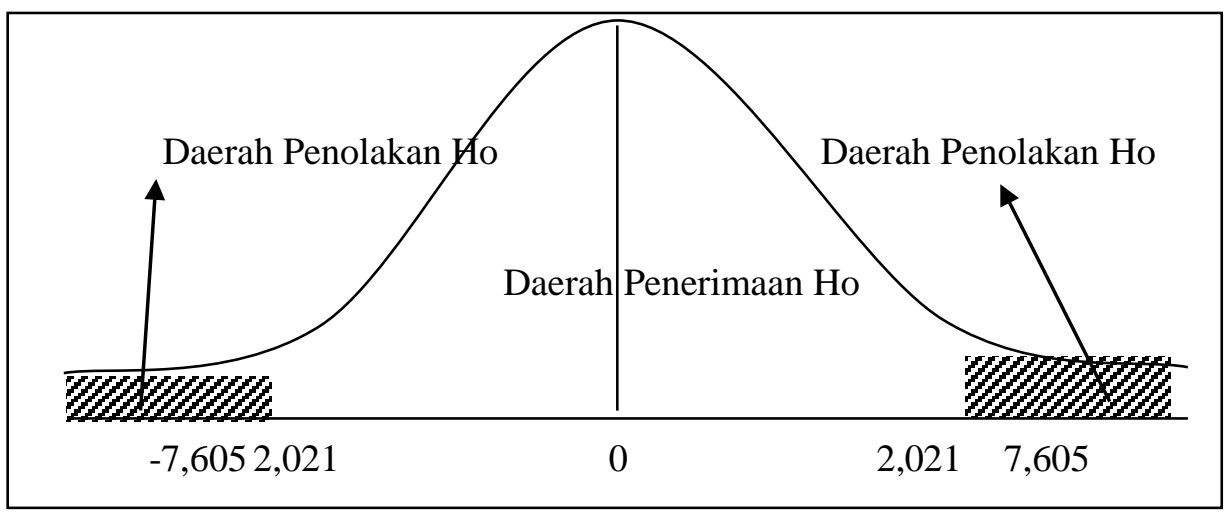

Sumber : Peneliti

Gambar 1.

Uji signifikan koefisien korelasi dengan uji dua pihak 
(a) Ho diterima jika $t_{\text {hitung }}<t_{\text {tabel }}$ atau 7,605 $<2,101$

(b) Ha diterima thitung $>$ ttabel atau 7,605> 2,101

Dari hasil pengujian diatas menunjukkan bahwa $t_{\text {tabel }}$ dengan $\alpha=5 \%$ untuk uji dua pihak $(\mathrm{dk})=\mathrm{n}-2$ adalah 7,605 dari hasil perhitungan diperoleh $\mathrm{t}_{\text {hitung }}>\mathrm{t}_{\text {tabel }}(7,605>2,021)$ maka Ho ditolak dan Ha diterima, berarti koefisien korelasi positif dan signifikan. Maka dapat disimpulkan bahwa terdapat pengaruh yang signifikan antara variabel $X$ (konsep diri siswa) terhadap variabel Y (prestasi belajar ekonomi) pada mata pelajaran akuntansi.

\section{Discussion}

Hasil perhitungan korelasi diatas dapat disimpulkan bahwa koefisien korelasi $r_{\mathrm{xy}}=0,765$ artinya terdapat hubungan yang kuat antara konsep diri siswa terhadap prestasi belajar ekonomi akuntansi. Angka ini merupakan hasil paling tinggi jika dibandingkan dengan hasil penelitian Szumski \& Karwowski (2019) pada pembelajaran matematika dengan nilai korelasi 0,42; hasil penelitian Wiyani (2013) pada pembelajaran ekonomi dengan koefisien korelasi sebesar 0,32 dan hasil penelitian Sulastri \& Setiawan (2013) pada pembelajaran Akuntasi dengan koefisien korelasi sebesar 0,496.

Koefisien korelasi yang tinggi pada hasil penelitian ini diduga disebabkan karena guru-guru di SMK Walisongo dalam mengajar menekankan konsep diri yang positif kepada peserta didik. Guru yang dalam mengajar juga menyisipkan materi pengembangan konsep diri yang positif dapat meningkatkan kematangan kepribadian siswa yang dapat meningkatkan prestasi belajar (Guay et al., 2019). Namun dugaan ini perlu dilakukan kajian kualitatif mendalam untuk melihat proses belajar mengajar yang terjadi di kelas.

Konsep diri memberikan kontribusi terhadap prestasi belajar ekonomi akuntansi sebesar 58,225\% sedangkan sisanya sebesar $41,775 \%$ dipengaruhi oleh faktor-faktor lain yang tidak diikutsertakan dalam penelitian ini. Angka ini pun tergolong tinggi karena hasil koefisien korelasi yang tinggi. Padahal jika merujuk kepada Slameto (2010:54) factor-faktor yang mempengaruhi prestasi peserta didik terbagi atas internal dan eksternal yang masing-masing bagian tersebut memiliki cukup banyak jenisnya. Temuan ini menarik untuk dilakukan kajian lebih mendalam.

Hasil penghitungan persamaan regresinya, yaitu $\mathrm{Y}=17,91+0,805 \mathrm{X}$. Nilai konstanta sebesar 17,91 yang berarti jika koefisien konsep diri nilainya adalah 0 , maka nilai prestasi belajar adalah 17,91. Koefisien regresi variable konsep diri sebesar 0,805 yang berarti jika terjadi kenaikan konsep diri sebesar 1 poin maka akan terjadi peningkatan prestasi belajar sebesar 0,805 poin. Temuan ini memiliki hasil yang hampir sama dengan penelitian sebelumnya dimana dengan sampel siswa yang belajar mata pelajaran Akuntansi memiliki persamaan regresi $\mathrm{Y}=16,645+0,704 \mathrm{X}$ (Sulastri $\&$ Setiawan, 2013). Sedangkan hasil lain dengan sampel penelitian adalah para siswa yang belajar IPA didapatkan persamaan regresi $\mathrm{Y}=10,06+0,36 \mathrm{X}$ (Andinny, 2015). Maka dapat ditarik kesimpulan sementara bahwa persamaan mata pelajaran akan menghasilkan konsep diri yang sama.

Hasil pengujian hipotesis diperoleh $t_{\text {hitung }}>t_{\text {tabel }}(7,605>2,021)$ maka Ho ditolak dan Ha diterima, berarti koefisien korelasi positif dan signifikan. Maka dapat disimpulkan bahwa terdapat pengaruh yang signifikan antara variabel X (konsep diri siswa) terhadap variabel Y (prestasi belajar ekonomi) pada mata pelajaran akuntansi. Hasil penelitian ini sejalan dengan hasil penelitian lain yang menyatakan konsep diri memiliki pengaruh positif dan signifikan terhadap prestasi belajar siswa (Ahmad, 2015; Bardach, Yanagida, Schober, \& Lüftenegger, 2019; Hartuti, 2015; Rosa, 2012; Sewasew \& Schroeders, 2019; Sulastri \& Setiawan, 2013). 


\section{CONCLUSION}

Berdasarkan pembahasan tersebut diatas dapat disimpulkan bahwa konsep diri memiliki pengaruh yang positif dan signifikan terhadap prestasi belajar peserta didik pada Mata Pelajaran Akuntasi di SMK Walisongo Jakarta Selatan. Koefisien korelasi dan Koefisien Determinasi yang didapatkan lebih besar dibandingkan dengan hasil-hasil penelitian sebelumnya. Hal ini diduga dalam proses pembelajaran para guru di SMK Walisongo mengajarkan konsep diri yang positif terhadap para siswa. Para guru di SMK Walisongo diharapkan minimal mempertahankan atau meningkatkan proses pembelajaran yang dapat meningkatkan konsep diri siswa. Untuk penelitian selanjutnya perlu dilakukan kajian kualitatif mengenai proses pembelajaran di SMK Walisongo karena penelitian ini memiliki keterbatasan tidak melihat proses pembelajaran di kelas.

\section{ACKNOWLEDGEMENTS}

Terimakasih penulis ucapkan kepada saudara Irano Tunung Saputro yang telah membantu penulis dalam penyebaran kuesioner dan mendampingi selama proses penelitian di SMK Walisongo Jakarta.

\section{REFERENCES}

Ahmad, D. N. (2015). Pengaruh Kemampuan Berpikir Kritik dan Konsep Diri terhadap Prestasi Belajar IPA. Formatif: Jurnal Ilmiah Pendidikan MIPA, 5(1), 55-67. https://doi.org/10.30998/formatif.v5i1.162

Alamsyah, N. (2016). Pengaruh Konsep diri Terhadap Prestasi Belajar Matematika Siswa SMAN 102 Jakarta. Jurnal Satuan Artikel Pendidikan, 1(2), 155-164.

Andinny, Y. (2015). Pengaruh Konsep Diri dan Berpikir Positif terhadap Prestasi Belajar Matematika Siswa. Formatif: Jurnal Ilmiah Pendidikan MIPA, 3(2), 126-135. https://doi.org/10.30998/formatif.v3i2.119

Bardach, L., Yanagida, T., Schober, B., \& Lüftenegger, M. (2019). Students ' and teachers ' perceptions of goal structures - Will they ever converge? Exploring changes in student-teacher agreement and reciprocal relations to self-concept and achievement. Contemporary Educational Psychology, 59(August), 101799. https://doi.org/10.1016/j.cedpsych.2019.101799

Darmastuti, H., \& Karwanto. (2014). Kualitas Pembelajaran Pada Jurusan Teknik Komputer Dan Informatika Di SMK Negeri 2 Surabaya. Jurnal Inspirasi Manajemen Pendidikan, 3(3), 9-20.

Fortunately, R., Asmendri, A., \& M. Haviz, M. H. (2019). Pengaruh Iklim Organisasi Dan Budaya Organisasi Terhadap Kinerja Guru Di Sma Negeri 1 Pariangan. AlFikrah: $\quad J u r n a l \quad M a n a j e m e n \quad$ Pendidikan, 7(2), 87-96. https://doi.org/10.31958/jaf.v7i2.1592

Gerritsen-van Leeuwenkamp, K. J., Joosten-ten Brinke, D., \& Kester, L. (2019). Students' perceptions of assessment quality related to their learning approaches and learning outcomes. Studies in Educational Evaluation, 63(July 2018), 72-82. https://doi.org/10.1016/j.stueduc.2019.07.005

Ghufron, M.N. dan Rini R. S. (2010). Teori-teori Psikologi. Yogyakarta: Ar-ruz Media Grup

Gorard, S. (2004). Quantitative Methods in Social Science. https://doi.org/10.1017/CBO9781107415324.004 
Guay, F., Stupnisky, R., Boivin, M., Japel, C., \& Dionne, G. (2019). Teachers' relatedness with students as a predictor of students' intrinsic motivation, selfconcept , and reading achievement. Early Childhood Research Quarterly, 48, 215225. https://doi.org/10.1016/j.ecresq.2019.03.005

Hartuti, P. M. (2015). Peran Konsep Diri, Minat dan Kebiasaan Belajar Peserta Didik terhadap Prestasi Belajar Fisika. Formatif: Jurnal Ilmiah Pendidikan MIPA, 5(2), 91-99. https://doi.org/10.30998/formatif.v5i2.329

Iim Inayah, \& Khoiri, N. (2013). Studi Komparasi Model Pembelajaran Two Stay Two Stray Dengan Metode Diskusi Dan Model Direct Intruction Dengan Metode Resitasi Berbantuan Buku Saku Terhadap Aktivitas Dan Hasil Belajar Kognitif Siswa. Jurnal Penelitian Pembelajaran Fisika, 4(9), 1-5. https://doi.org/10.1017/CBO9781107415324.004

Indriaturrahmi, \& Sudiyatno. (2016). Peran Dunia Usaha Dan Dunia Industri Dalam Penyelenggaraan SMK Berbasis Kearifan Lokal Di Kota Mataram. Jurnal Pendidikan Vokasi, 6(2), 162-172.

Kamdi, W. (2017). Revitalisasi SMK: Mendongkrak Unggulan Nasional. Direktorat Pembinaan SMK Direktorat Jenderal Pendidikan Dasar Dan Menengah Kementerian Pendidikan Dan Kebudayaan, p. 1. Retrieved from http://psmk.kemdikbud.go.id/konten/2637/revitalisasi-smk-mendongkrakunggulan-nasional

Magfirah, I., Rahman, U., \& Sulasteri, S. (2015). Pengaruh Konsep Diri Dan Kebiasaan Belajar Terhadap Hasil Belajar Matematika Siswa Kelas VIII SMP Negeri 6 Bontomatene Kepulauan Selayar. Jurnal Matematika Dan Pembelajaran, 3(03), 103-116.

Mynott, G. J. (2018). The academic self-concept of business and management students: A review of the literature. The International Journal of Management Education, 16(3), 515-523. https://doi.org/10.1016/j.ijme.2018.10.003

Nurfarhana, A., Abdillah, A., \& Prasetyono, H. (2017). Faktor Yang Berpengaruh Terhadap Disiplin Kerja Guru SMKN 1 Depok Dan SMKS Yapan Indonesia. Jurnal Research and Development Journal Of Education, 44(22), 3-22.

Poerwadarminta, W.J.S. (2005). Kamus Umum Bahasa Indonesia Edisi Ketiga. Jakarta: Bahari Pustaka

Prasetyono, H., Abdillah, A., Widiarto, T., \& Sriyono, H. (2018). Character-based Economic Learning Implementation and Teacher's Reinforcement on Student's Affective Competence in Minimizing Hoax. Cakrawala Pendidikan, 37(3), 426435.

Prasetyono, Hendro, Abdillah, A., \& Fitria, D. (2018). Academic Supervision toward Teacher' s Performance through Motivation as Intervening Variable. Journal of Education and Learning (EduLearn), 12(2), 188-197. https://doi.org/10.11591/edulearn.v12i2.7324

Putro, A. R. T. S., \& Triyono, M. B. (2016). Pengelolaan Labkom Di Sekolah Menengah Kejuruan. Jurnal Pendidikan Vokasi, 6(2), 143-153.

Rakhmat, Jalaludin. (2007). Persepsi dalam Proses Belajar Mengajar. Jakarta: Rajawali Press

Rosa, N. M. (2012). Pengaruh Sikap Pada Mata Pelajaran Kimia Dan Konsep Diri Terhadap Prestasi Belajar Kimia. Jurnal Formatif, 2(3), 218-226. https://doi.org/10.30998/formatif.v2i3.104

Saputra, S., \& Prasetyono, H. (2020). The Effect of Scientific Approach to The Activity of Learning Students in SMPN 25 Tangerang City. Jurnal PAJAR ( Pendidikan Dan Pengajaran ), 4(1), 20-30.

Sekaran, U. (2003). Research Methods For Business A Skill-Building Approach (4th ed.). 
New York: John Wiley \& Sons, Inc.

Slameto. (2003). Belajar dan Faktor-Faktor yang Mempengaruhinya. Jakarta: Rineka Cipta.

Sobur, A. (2013). Filsafat Komunikasi. Bandung: PT. Remaja Rosdakarya

Setiawati, L. (2015). Faktor-Faktor Yang Mempengaruhi Prestasi Belajar Praktik Kejuruan Siswa SMK Program Studi Keahlian Teknik Komputer Dan Informatika. Jurnal Pendidikan Vokasi, 5(3), 325-339.

Sewasew, D., \& Schroeders, U. (2019). The developmental interplay of academic selfconcept and achievement within and across domains among primary school students is. Contemporary Educational Psychology, 58(March), 204-212. https://doi.org/10.1016/j.cedpsych.2019.03.009

Sugiyono. (2010). Metode Penelitian Pendidikan. Bandung: Alfabeta.

Sulastri, S. S., \& Setiawan, N. (2013). Pengaruh Konsep Diri Dan Kebiasaan Belajar Terhadap Hasil Belajar Akuntansi Siswa Kelas XI IPS Madrasah Aliyah Negeri Yogyakarta II Tahun Ajaran 2011/2012. Kajian Pendidikan Akuntansi Indonesia, 2(1), 226-225.

Surjanti, J., Soejoto, A., \& Nugroho, D. (2020). Mangrove forest ecotourism: Participatory ecological learning and sustainability of students' behavior through self-efficacy and self-concept. Social Sciences \& Humanities Open, 2(1), 100009. https://doi.org/10.1016/j.ssaho.2019.100009

Surna, I.N. dan Panderiot, O.D. (2014). Psikologi Pendidikan 1. Jakarta: Erlangga

Sutrisno, V. L. P., \& Siswanto, B. T. (2016). Faktor-Faktor Yang Mempengaruhi Hasil Belajar Siswa Pada Pembelajaran Praktik Kelistrikan Otomotif SMK Di Kota Yogyakarta. Jurnal Pendidikan Vokasi, 6(1), 111-120.

Szumski, G., \& Karwowski, M. (2019). Exploring the Pygmalion effect: The role of teacher expectations, academic self-concept, and class context in students' math achievement. Contemporary Educational Psychology, 59(June), 101787. https://doi.org/10.1016/j.cedpsych.2019.101787

Tamrin, A. G., PH, S., \& Soenarto. (2018). The Link And Match Of The Demand And Supply For Productive Vocational School Teachers With Regard To Spectrum Of Vocational Skills In The Perspective Of Education Decentralization. Jurnal Pendidikan Vokasi, 8(1), 40-52.

Thomas, P. (2013). Faktor Determinan Produktivitas Sekolah. Jurnal Penelitian Dan Evaluasi Pendidikan, 17(1), 55-71.

Tu'u, T. (2004). Peran Disiplin pada Prilaku dan Prestasi Siswa. Jakarta: PT. Grasindo

Warren, J. M., \& Hale, R. W. (2016). The Influence of Efficacy Beliefs on Teacher Performance and Student Success: Implications for Student Support Services. Journal of Rational - Emotive and Cognitive - Behavior Therapy, 34(3), 187-208. https://doi.org/10.1007/s10942-016-0237-z

Wiyani, T. E. K. (2013). Pengaruh Konsep Diri, Kemandirian, Motivasi Dan Lingkungan Belajar Terhadap Prestasi Belajar Ekonomi Siswa Kelas XI IPS SMA Negeri Di Kabupaten Gresik. Jurnal Ekonomi Pendidikan Dan Kewirausahaan, 1(2), 130139. https://doi.org/10.26740/jepk.v1n2.p130-139 